\title{
EMPIRICAL RESEARCH ON BUSINESS AWARENESS CONCERNING WORKPLACE CRĖCHES
}

\section{VÁLLALKOZÓI TUDATOSSÁG EMPRIKUS KUTATÁSA MUNKAHELYI BÖLCSÖDÉVEL KAPCSOLATBAN}

\author{
Henrietta Tóthné Dóra ${ }^{1}$, Kata Földi ${ }^{21}$ \\ ${ }^{1}$ Educations Faculty, Charles Eszterházy University, Hungary \\ ${ }^{2}$ Commerce, Marketing and International Business Department, Business Administration Faculty, \\ John von Neumann University, Hungary
}

\author{
Keywords: \\ business awareness \\ workplace crèches \\ establishing and maintenance \\ state subsidies \\ empirical research \\ Kulcsszavak: \\ vállalkozói tudatosság \\ munkahelyi bölcsőde \\ létesítés és fenntartás \\ állami támogatás \\ empirikus kutatás \\ szolgáltatás
}

\begin{abstract}
Our objective with the empirical research was to learn about the opinion of business leaders about the new form of care, and to get an explanation why the opportunity to create a crèche in the workplace is not being used by today's companies, despite the facilitating state environment (financial funding for tender funds and favorable personal conditions). Our further goal was to formulate suggestions for business leaders to raise awareness of workplace crèches.

Összefoglalás

Célunk volt megismerni empirikus kutatással a vállalkozások vezetöinek véleményét az új ellátási formát illetően, illetve magyarázatot kapni, miért nem élnek a munkahelyi bölcsőde létrehozásának lehetőségével napjaink vállalkozásai a facilitáló állami környezet (pénzügyi finanszírozásra pályázati forrás és kedvező személyi feltételek) ellenére sem. További célunk volt javaslatokat megfogalmazni a vállalkozások vezetőinek tudatosság növelésére a munkahelyi bölcsődékkel kapcsolatban.
\end{abstract}

\section{Introduction}

The relevance of our topic is that nowadays the compatibility of family and work, the reintegration of women in the labor market, and the increase of the number of crèche places are increasingly emphasized in the social policy manifestations of the European Union,

\footnotetext{
1 contact author: +3656516066

E-mail address: foldi.kata@gk.uni-neumann.hu, dr.foldi.kata@freemail.hu
} 
including Hungary. As of January 1, 2017, other day care alternatives such as mini crèche, workplace crèche, family crèche and day care are also available on the basis of the new day nursery system for children [1].

The current national policy of Hungary pays special attention to families, recognizing the need for a flexible and adaptable (fashionable phrase: resilient) approach, in order to increase the number of the population, while at the same time reconciling the workforce and the world of work. "Having a chance to work with motherhood is worth much more than family benefits [2].

Our choice of topic is justified by the fact that one of the authors has been working in a profit-making enterprise for decades, whose owner is thinking about creating and maintaining a workplace crèche, while the other author has had unpleasant experiences at the factory nursery in the Szolnok Chemical Company in her childhood.

Our goal is to get to know business leaders' views on the new form of care, and to obtain a reason why the opportunity to create a workplace crèche is not being used by today's businesses, despite the facilitating state environment. Based on the opinion of these managers, we examine why this form of child care has not spread again, even though it used to be a good practice to operate a workplace crèche.

\section{Methodology}

To achieve our goal, we conducted a literature review, secondary research and primary (qualitative and quantitative) research. Due to dimensional constraints, we do not address either qualitative or quantitative research, examining the basic population with small children.

\subsection{Literature Review}

The first crèches in Europe were established in the middle of the 19th century, at the end of the first wave of the Industrial Revolution (the first crèche was actually opened in Paris on November 4, 1844), and in Hungary on April 21, 1852 [3]. According to the data of the Hungarian Central Statistical Office, the proportion of workplace crèches in Hungary was the highest in 1951 (56.6\%), and then decreased in the following decades. In 1980, $20 \%$ of operating crèches were workplace crèches, in 1990 only $8,5 \%$ and at the turn of the millennium, there was no operating crèches at all.

Amendments to the Child Protection Act, effective from 1 January 2017, renewed the crèche system, part of which includes the old-new form of care, the workplace crèche, the spreading of which is being promoted by the state with various subsidies (financially with a tender source, more favorable personal conditions).

A workplace crèche is a crèche care service, maintained by the employer, primarily for the children of the employees. The workplace crèche accommodates children from 20 weeks to 3 years of age, and children with special needs can benefit from care until the 31st of August of the year in which they are 6 years old. The daily care time can be 4-12 hours. In addition to crèche care services, services can also be organized based on the needs of families working at the employer (e.g. periodic childcare). Workplace crèche can be operated by any type of employer. It does not qualify as an institution, therefore, the regulation on its establishment and operation differs from traditional crèche care in some respects, however, the chapters of the national nursery care program cover all forms of nursery care, such as crèche nursery. It is an activity linked to the registration in a service provider register, which is performed, based on an electronic request to the government office with territorial competence [4].

\subsection{Secondary Research}

In recent years, the employment rate of women with children has steadily improved and reached $61.2 \%$ in 2017, a significant increase (11.3 percentage points) compared to 2010 (49.9 $\%)$. At the same time, the employment rate for women with children under 3 years of age is still particularly low, in comparison with other EU countries. One key element in promoting this target group's employment is their easy access to financially reasonable day-care for their children, which is not only in employees' interest, but also favorable for employers who often suffer from labor shortages. 
The support is available for training and employment of people providing nursery care (salary and social contribution tax), for administrative costs related to the establishment, as well as for the acquisition of the necessary equipment and provision and development of the service location. In addition, the employer may apply for support for the training and competence development of the parent returning to work. At the time of announcing the Call for Proposals, the planned amount of funding available for support was HUF 6 billion. Submission of grant applications was possible from 20 March 2017 until 20 March 2019 (but closed on 2 November 2018). The amount of the non-refundable grant is: minimum HUF 8 million, maximum HUF 100 million. The maximum amount of support depends on the eligible activity: in case of training aid $-70 \%$ for a large enterprise, $100 \%$ for de minims aid. [5]

According to the data of the Central Statistical Office, from 2017 to 2018 the number of workplace crèches to 8 ( $1 \%$ of the number of crèches), thus providing 56 beds $(0.14 \%$ of the total capacity), with the provision of 16 teachers for 51 children. [6]

\subsection{Primary Research}

The survey was conducted using standardized, online questionnaires (using the Gmail Google Drive Form Filler). The questionnaire was shared on the most well-known Internet social networking site. For the entrepreneurship it was accessible by registering in a closed group called the 'HR Club', the 'Entrepreneurs' Association' and the 'Professional and Friendly Circle of HR Professionals', thus ensuring a sampling by a concentrated selection method. In addition, the link to the online questionnaire was shared by email too. Each year, the relevant regional chambers publish a list of 'TOP5O and TOP100 businesses', which rank the companies in Hungary with the highest number of employees and the highest annual net sales. Based on the annual lists of businesses between 2015-2018, visiting their websites, we created a database of their e-mail addresses, based on which 200 e-mails were sent to the HR managers. The number of respondents was 106 and the number of questionnaires was 106. The population is 508,609 (CSO 2018). The sample is $0.002 \%$ of the base population.

The sample is overrepresented by women, those aged between 25-45 and those with children - nearly two thirds of the respondents. The manager is overrepresented (nearly one third of the respondents), more than one fifth of the respondents are HR managers, and over $10 \%$ are financial managers or HR assistants. $85 \%$ of the respondents work either in these five job roles. The sample is overrepresented by employees of urban businesses and industry sectors. The former is nearly $50 \%$, the latter nearly $40 \%$. More than one third of the respondents work in county seats and more than $10 \%$ in the capital city. More than a fifth of the company's core business is in trade and nearly a fifth in education. Businesses with number of employees over 50 was overrepresented among the respondents. Nearly $40 \%$ of the respondents do not know how many percent of their employees have children under 3 years of age, and nearly a third of them think it is between $11-25 \%$.

The questionnaire was completed in a self-filling manner between 2 November 2018 and 3 March, 2019. The questionnaires were processed using IBM SPSS Statistics 20, which facilitated the use of mathematical - statistical calculations.

The questionnaire contained 25 questions, some of which were partly open, partly closed, and completely open. With the closed questions, we tried to describe the answers given in the topic as subtle as possible. Accordingly, at the "other" category for closed questions it was possible to express an independent opinion. Two of the closed questions were a 5-point Likert scale question, which provided a greater opportunity for statistical calculations, so it was possible to determine the mean and standard deviation (showing the strength of agreement) during processing. In the processing of the responses, statistical analysis methods were applied according to the topic, as mentioned above: the mean and standard deviation indicators were examined. The tables presented for illustrative purposes mainly show the proportions of the respondents. 


\section{Results}

More than half of the respondents (58.5\%) responded to an open question, asking about the reasons for the existence of many workplace crèches before the change of regime and the reason for their absence today.

The response of 62 respondents is illustrated by the word cloud in Figure 1, which illustrates the most common responses with a larger font size.

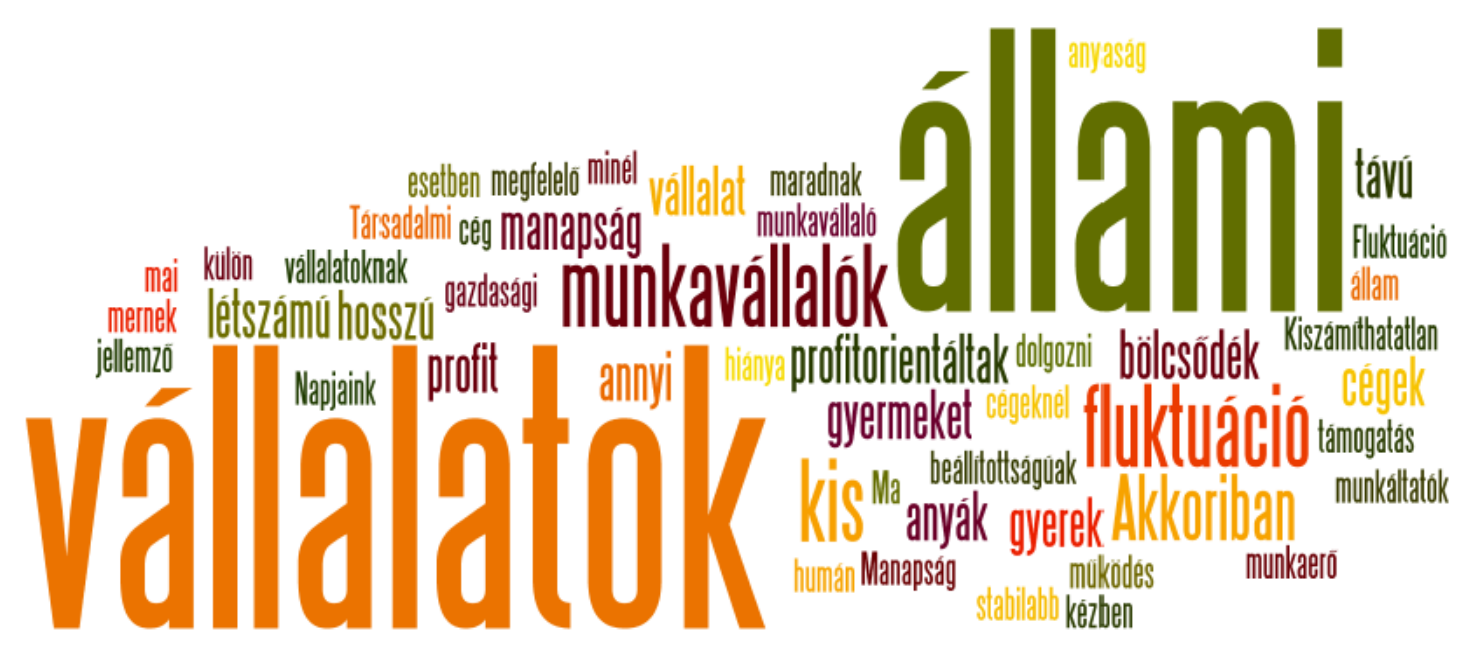

Figure 1 The reasons for the past successes of the workplace crèche and the lack of it today ( $N=62$ people) 50 word cloud

As a reason for the success of the workplace crèches in the past, the majority identified the state-owned corporate form and the full state funding of the establishment and maintenance. In our opinion, this view is best summarized in the following two opinions: "Many factories and companies were operating, usually in several shifts. It was good for the workers that in the early morning or late afternoon, they did not have to take their child to crèche on separate roads with extra time. During the day, they could know their child in the vicinity, or they could visit them." "In the socialism, businesses were not interested in operating as a real enterprise with the state financing the losses, so they were able to carry out all kinds of profitable activities - close to or part of their main operating area -, in many cases taking over the social policy tasks of the state."

Nowadays, the lack of workplace crèches is mainly due to company leadership values (profit orientation), leadership theory (X theory), financial resources (maintenance and operation), business characteristics (e.g. size) or employee needs (fewer children are born, íreturn to work after 3 years, fluctuations, shifts).

This is supported by the following three opinions:

"Today, there are companies with small number of employees, mothers often return to work after 3 years, or they give birth to children one after the other, and they get out of work for many years."

"Social responsibility has been pushed into the background, everyone strives to maximize profit. The level of social solidarity is low."

"In large companies with a lot of employees, people usually work in shifts, which is not very suitable for setting up workplace crèches. Employees travel long distances between their place of residence and their workplace and so commuting with kids is not advisable."

The following answer justifies the idea of a family-friendly workplace with its forwardlooking nature:

"Most employers do not deal with the issue, they think it would be a big investment and they would not have a great deal of ease for employees." 
Less than one-tenth of the respondents (9 people) have access to periodic childcare. This is realized primarily as a summer camp ( 4 people), day care ( 3 people), nursery ( 1 person) and babysitter (1 person).

Nearly half of employees return to work after 2 years, and a third after 3 years. By contrast, it would be beneficial for businesses if employees returned to work within 1 year (just over $40 \%$ ), within half a year, according to nearly one-fifth of respondent, between one and two years of age, according to again one-fifth, and just over $10 \%$ of them after 2 years (child care expiry date). The distance from the workplace to the nearest crèche, according to more than a third of the respondents, is within $3-5 \mathrm{~km}$, according to nearly a third, between $1-2 \mathrm{~km}$ and according to nearly one fifth, within $1 \mathrm{~km}$.

The knowledge of basic information about setting up and maintaining a workplace crèches has been measured in Question 14, which gives an insight into extremely low awareness. Less than a fifth of respondents knew that a 100-hour course would be enough to supervise young children and an external service provider could be invited to operate. Nearly one-fifth of the respondents knew that they could be operated even with 5 children. Just over one-fifth of the respondents knew that $95 \%$ state support was available for the creation of a workplace crèche, with state normative action and catering even by delivery can be provided. There is very little awareness of the basic information about setting up and maintaining a workplace crèche. Table 1 illustrates this.

Table 1 Knowledge of basic information about setting up and maintaining a workplace crèche $(N=106$ people $)$

\begin{tabular}{|l|l|c|c|}
\hline \multirow{2}{*}{ Number } & \multicolumn{1}{|c|}{ Information } & \multicolumn{2}{c|}{ Awareness (\%) } \\
\cline { 3 - 4 } & & YES & NO \\
\hline 1. & 95\% state support can be applied to create a workplace crèche & 27.4 & 72.6 \\
\hline 2. & State norms can be applied for its operation & 26.4 & 73.6 \\
\hline 3. & Operation is possible even with 5 children & 21.7 & 78.3 \\
\hline 4. & Meals can be delivered too & 26.4 & 73.6 \\
\hline 5. & External service provider may be invited to operate & 17.0 & 83.0 \\
\hline 6. & a 100-hour course would be enough to supervise young children & 14.2 & 85.8 \\
\hline
\end{tabular}

Less than $10 \%$ of the respondents (9 people) had a needs assessment for the establishment of a workplace crèche among employees, of which $2(1.9 \%)$ did not need it. In almost three-quarters, there was no needs assessment at all, and is not even planned, and nearly a fifth of them has not done it yet but planning to perform a needs assessment. More than half of the respondents (58.5\%) said their company would not create a workplace nursery with 95\% funding, nearly one-third (29.2 \%) might and just over $10 \%$ (12.3 \%) would establish a workplace crèche.

Respondents said that the biggest problem with creating a workplace crèche would be to provide space, then create statistics, extra-work with documentation, staff / HR criteria and creation. The least of the problems would be the number of children or the public health criteria. The order of factor assessment and the average and standard deviation of the 5 -degree Likert scale for the question "Which of the conditions of creating a workplace crèche would cause problems" are shown in Table 2.

Table 2 Which of the conditions for creating a workplace crèche would cause a problem assessed on a 5-grade Likert scale (1: least problem, 5: most problem)

\begin{tabular}{|l|l|l|l|l|}
\hline \multicolumn{1}{|c|}{ Order } & \multicolumn{1}{|c|}{ Factors } & Average & $\begin{array}{l}\text { Standard } \\
\text { deviation }\end{array}$ & $\begin{array}{c}\text { Relative } \\
\text { deviation (\%) }\end{array}$ \\
\hline 1. & Provision of space & 3.95 & 1.21 & 30.63 \\
\hline 2. & Statistics, extra work with documentation & 3.93 & 1.26 & 32.06 \\
\hline 3. & HR criteria & 3.92 & 1.14 & 29.08 \\
\hline
\end{tabular}




\begin{tabular}{|l|l|l|l|l|}
\hline 4. & Staff for the establishment & 3.92 & 1.19 & 30.36 \\
\hline 5. & Material criteria & 3.80 & 1.11 & 29.21 \\
\hline 6. & Finance & 3.66 & 1.34 & 36.61 \\
\hline 7. & Capital required for the foundation & 3.42 & 1.09 & 31.87 \\
\hline 8. & Public health criteria & 3.11 & 1.07 & 34.41 \\
\hline 9. & Number of children & 2.87 & 1.06 & 36.93 \\
\hline
\end{tabular}

The standard deviation is the greatest in terms of financing and statistics, extra work with documentation, i.e. the respondents are the least likely to agree. The relative standard deviation (i.e. the standard deviation in percentage of the mean) is around $30 \%$ for each factor, which causes the typical strength of average to be questioned for each factor. Nearly half of the respondents (46.2 \%) thought that if there were any companies that would carry out tasks related to the establishment and operation of the crèche, their company would use its services. Almost the same (40.6\%) believed that they would probably use it and barely more than oneeighth of the respondents would not use it at all (13.2\%). Nearly seven-tenths of the respondents $(68.9 \%)$ would only ask parents to pay a fee for the use of the workplace crèche, so that the costs would be reimbursed and just over a fifth (20.8 \%) would ask for a usage fee that would make a profit and hardly more than ten percent said it would be free.

For employees, the faster return from childcare to work, more loyalty and greater confidence in the company were indicated as the factors resulting from the existence of a workplace crèche. According to the respondents, the change in work efficiency and the decrease in morning delays would be the least. Table 3 shows the average and standard deviation of the impact of workplace crèches on employees.

Table 3 Assessing the impact of workplace crèches on a 5-point Likert scale

\begin{tabular}{|l|l|l|l|l|}
\hline Order & \multicolumn{1}{|c|}{ Factors } & \multicolumn{1}{|c|}{ average } & $\begin{array}{l}\text { Standard } \\
\text { deviation }\end{array}$ & $\begin{array}{l}\text { Relative } \\
\text { deviation }\end{array}$ \\
\hline 1. & Faster return from childcare to work & 4.26 & 0.89 & 20.89 \\
\hline 2. & Increased loyalty to the company & 3.88 & 0.94 & 24.23 \\
\hline 3. & Increased trust towards the company & 3.80 & 0.84 & 22.11 \\
\hline 4. & $\begin{array}{l}\text { Workplace choices are more motivated towards a } \\
\text { specific company }\end{array}$ & 3.78 & 0.87 & 23.02 \\
\hline 5. & Growth in childbirth & 3.73 & 1.24 & 33.24 \\
\hline 6. & $\begin{array}{l}\text { Employees easier identify themselves with company's } \\
\text { objectives }\end{array}$ & 3.69 & 0.87 & 23.58 \\
\hline 7. & More committed work & 3.67 & 0.87 & 23.71 \\
\hline 8. & More efficient work & 3.42 & 1.04 & 30.41 \\
\hline 9. & Reduced morning delays & 2.97 & 1.18 & 39.73 \\
\hline 10. & Reduced absence due to childcare allowance days & 2.93 & 1.17 & 39.33 \\
\hline 11. & Taking more shifts & 2.36 & 1.12 & 47.46 \\
\hline
\end{tabular}

For three factors (increase in childbirth, decrease in morning delays and reduction in childcare allowance days), the deviation is the highest, i.e. respondents agree the least. The relative standard deviation (i.e. standard deviation in the percentage of the average) is $30 \%$ for 5 factors (increase in childbirth, more efficient work, reduced morning delays, reduction of childcare allowance days, and shifts), which casts doubt on the typical strength of average for these 5 factors. 


\section{Conclusions}

Business management does not have enough information on workplace crèches. The answers to questions about knowing the basics of establishing and maintaining a workplace crèche provide a very low level of awareness. We consider it necessary to inform the managers / owners of enterprises about the conditions for establishing and maintaining a workplace crèche (more favorable HR conditions), about funding opportunities to make a higher level of awareness, and to let them make a more informed decision on the matter.

\section{Acknowledgement}

This research is supported by EFOP-3.6.1-16-2016-00006 "The development and enhancement of the research potential at John von Neumann University" project. The Project is supported by the Hungarian Government and co-financed by the European Social Fund.

\section{Bibliographical References}

[1] XXXI of 1997. Act on the Protection of Children and Guardianship

[2] F. Szabó Kata (2018.04.23). Playing with Numbers. Vasarnapihirek.hu. [Online]. Available: https://www.vasarnapihirek.hu/fokusz/jatek a szamokkal 27626 [Downloaded: 23-August-2018].

[3] Aggné Pirka Veronika et al. (2014). Early Childhood Education and Family History Budapest: ELTE Tanítóés Ovóképző Faculty

[4] Workplace Crèche Information (2017) Efop311.hu. [Online]. Available: http://www.efop311.hu/wpcontent/uploads/2018/02/munkahelyi_bolcsode_tajekoztato.pdf [Downloaded: 25-Nov-2018].

[5] Call for the Creation of Workplace Crèches (code GINOP-5·3.8-17)

[6] Central Statistical Office Children's Day Care 2017-2018 [Online]. Available: http://www.ksh.hu/docs/hun/xstadat/xstadat eves/i fsg012.html [Downloaded: 03-Mar-2019]. 
(iii) 